\title{
Brief communication: Weak control of snow avalanche deposit volumes by paths morphological characteristics
}

Hippolyte Kern ${ }^{1}$, Nicolas Eckert ${ }^{2}$, Vincent Jomelli ${ }^{1,3}$, Delphine Grancher ${ }^{1}$, Michael Deschatres ${ }^{3}$, Gilles Arnaud-Fassetta ${ }^{4}$

5 1 Université Paris 1 Panthéon-Sorbonne, LGP-CNRS, 1 place Aristide Briand, Meudon, France

${ }^{2}$ UR ETNA, INRAe, Université Grenoble Alpes, Grenoble, France

${ }^{3}$ Aix-Marseille University, CNRS, IRD, Coll. France, INRAE, CEREGE, 13545 Aix-en-Provence, France

${ }^{4}$ Université de Paris, UMR 8586 PRODIG, 8, rue Albert Einstein, 75013 Paris, France

Correspondence to: Hippolyte Kern (hippolyte.kern@lgp.cnrs.fr)

10 Abstract: Snow avalanches are a major component of the mountain cryosphere, but little is known about the factors controlling the variability of their deposit volumes. This study investigates the influence of morphological characteristics on c. 1500 deposit volumes recorded between 2003 and 2018 in 77 snow avalanche paths of the French Alps. Different statistical techniques show a slight but significant link between deposit volumes and path mean elevation and orientation, with contrasted patterns between winter and spring seasons. The weakness, partially non-linear nature of this control may

15 result from the combined influence on the genesis of deposit volumes of mean path activity, climate conditions and mechanical thresholds determining avalanche release.

\section{Introduction}

Snow avalanches are a major component of the mountain cryosphere (Beniston et al., 2018) that often put people, settlements and infrastructures at risk. These gravitational processes consist in rapid and complex snow flows (Mc Clung and

20 Gauer, 2018). Despite significant progresses over recent years regarding the mechanical behavior of snow in motion and related flow regimes (Köhler et al., 2018), critical aspects of snow avalanche dynamics remain less known, such as the factors controlling deposit volumes. The latter limited knowledge is surprising as snow avalanche deposit characteristics determine the damage and disturbance to people, buildings and communication networks (Leone et al., 2015). Previous works documented the sedimentological characteristics of snow avalanche deposits (Jomelli and Bertran, 2001; Bartelt et al.,

25 2009). It has also been observed that snow characteristics may vary from the starting zone to the deposit area (Jomelli, 1999; Jomelli and Bertran, 2001). Research conducted on experimental sites in Switzerland (Sovilla et al., 2015; Kölher et al., 2018) or in Canada (Mc Clung and Gauer, 2018) showed weak links between avalanche deposit size, path slope and avalanche maximum frontal speed. However, factors driving the volumetric characteristics of avalanche deposits have never been explored in a systematic way on a basis of a large data set. Here, using an exceptional sample of 1491 snow avalanches 30 deposits volumes documented from 2003 to 2018 on 77 avalanche paths from the French Alps and using simple (descriptive) 
https://doi.org/10.5194/tc-2021-103

Preprint. Discussion started: 15 April 2021

(c) Author(s) 2021. CC BY 4.0 License.

(c) (i)

to advanced (deep learning) statistical techniques, we present a first detailed quantification of how paths morphological characteristics impact snow avalanche deposit volumes. Specifically, we show that the control of deposit volumes by path morphology is weak but significant.

\section{Data and methodology}

\section{$35 \quad 2.1$ Avalanche deposit volumes}

This research was conducted on the two hillsides of the upper part of the Maurienne valley in the Northern French Alps between the municipalities of Lanslevillard and Bonneval-sur-Arc (Fig. 1). Because of its important number of active avalanche paths, this study area is particularly relevant for our analysis (e.g., Eckert et al., 2009; Favier et al., 2014; Zgheib et al., 2020). The dataset of snow avalanche deposit volumes used in this study is primarily based on the Permanent

40 Avalanche Survey (EPA) which was created at the beginning of the $20^{\text {th }}$ century to document avalanche events as exhaustively as possible on more than 3,000 avalanche paths in the French Alps. For each single avalanche event, the size of the deposit is documented, based on a visual estimate carried out by devoted survey operators from the EPA network. For each deposit, the length, the width and the mean depth is estimated, which eventually provides a volume estimate. For each path, EPA operators systematically use the same predefined observation point, so as to maximize the accuracy of the estimation. However, a further correction and completion work was carried out to develop a more comprehensive and errorfree snow avalanche deposit database (Kern et al., 2020). Input errors or outliers introduced within the EPA when old records registered on paper archives were converted to numerical data were spotted and corrected. In addition, few other snow avalanche events (less than $1 \%$ of the total number of events) that were not included in the EPA were added from other sources: operational services in charge of hazard management and a citizen science dataset: data-avalanche.org.

50 From the entire deposit volume data set available since the beginning of the $20^{\text {th }}$ century (Kern et al., 2020), our study only uses data covering the period from November 2003 to June 2018 (15 "full" avalanche seasons). This limits the biases and inaccuracies induced by the estimation method which were much higher earlier due to less sharp topographical references available to the EPA operators and a less standardized observation protocol until the 2000s (Kern et al., 2020). Thus, our study includes 1491 single avalanche events and associated deposit volumes registered in 77 distinct paths (Fig. 1).

55 To analyse the possible links between path morphology and deposit volumes, we first computed the interannual mean deposit volume in each of these paths. Then, the same operation was done for both the winter (avalanches that occurred between $1^{\text {st }}$ of November and $29^{\text {th }}$ of February) and spring (avalanches that occurred from $1^{\text {st }}$ of March to $31^{\text {th }}$ of May) subseasons. Eventually, in order to investigate the potential influence of avalanche activity on deposit volumes, we evaluated the interannual mean number of avalanches per year and path, including within the computation snow avalanche records for

60 which deposit volumes could not be estimated. Seasonal (Nov-Feb and Mar-Jun) occurrence rates were also evaluated. The data from two weather stations handled by Météo-France and located at elevations of $1715 \mathrm{~m}$ a.s.l. and $2740 \mathrm{~m}$ a.s.l. in Bessans, respectively (Fig. 1), was analyzed in order to determine climate conditions having locally prevailed over the study 
https://doi.org/10.5194/tc-2021-103

Preprint. Discussion started: 15 April 2021

(c) Author(s) 2021. CC BY 4.0 License.

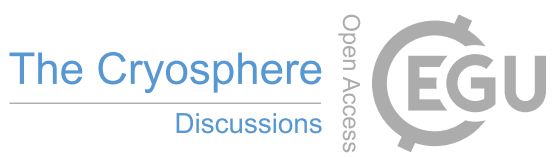

period. This showed that the depth of the local snowpack regularly exceeds $50 \mathrm{~cm}$ at $1715 \mathrm{~m}$ a.s. 1 . and $200 \mathrm{~cm}$ at $2740 \mathrm{~m}$ a.s.1.. The winter (Nov-Feb.) season is characterized by a cold mean air temperature $\left(-4^{\circ} \mathrm{C}\right.$ at $1715 \mathrm{~m}$ a.s.1., $-5.5^{\circ} \mathrm{C}$ at $2740 \mathrm{~m}$

65 a.s.1.), with heavy precipitation that nearly only fall in the form of snow but the depth of the snowpack remains relatively thin (90 $\mathrm{cm}$ at $2740 \mathrm{~m}$ a.s.1.). By contrast, the spring season is characterized by higher mean air temperatures $\left(3.5^{\circ} \mathrm{C}\right.$ at 1715 $\mathrm{m}$ a.s.l., $-2^{\circ} \mathrm{C}$ at $2740 \mathrm{~m}$ a.s.l.) and the occurrence of significant daily warm spells (daily mean air temperature up to $25^{\circ} \mathrm{C}$ at $1715 \mathrm{~m}$ a.s.l), which favors the occurrence of rain on snow events and wet snow avalanches. The mean daily fresh snowfall is twice lower than during the winter season, but, on average, the snowpack remains thick $(170 \mathrm{~cm})$.

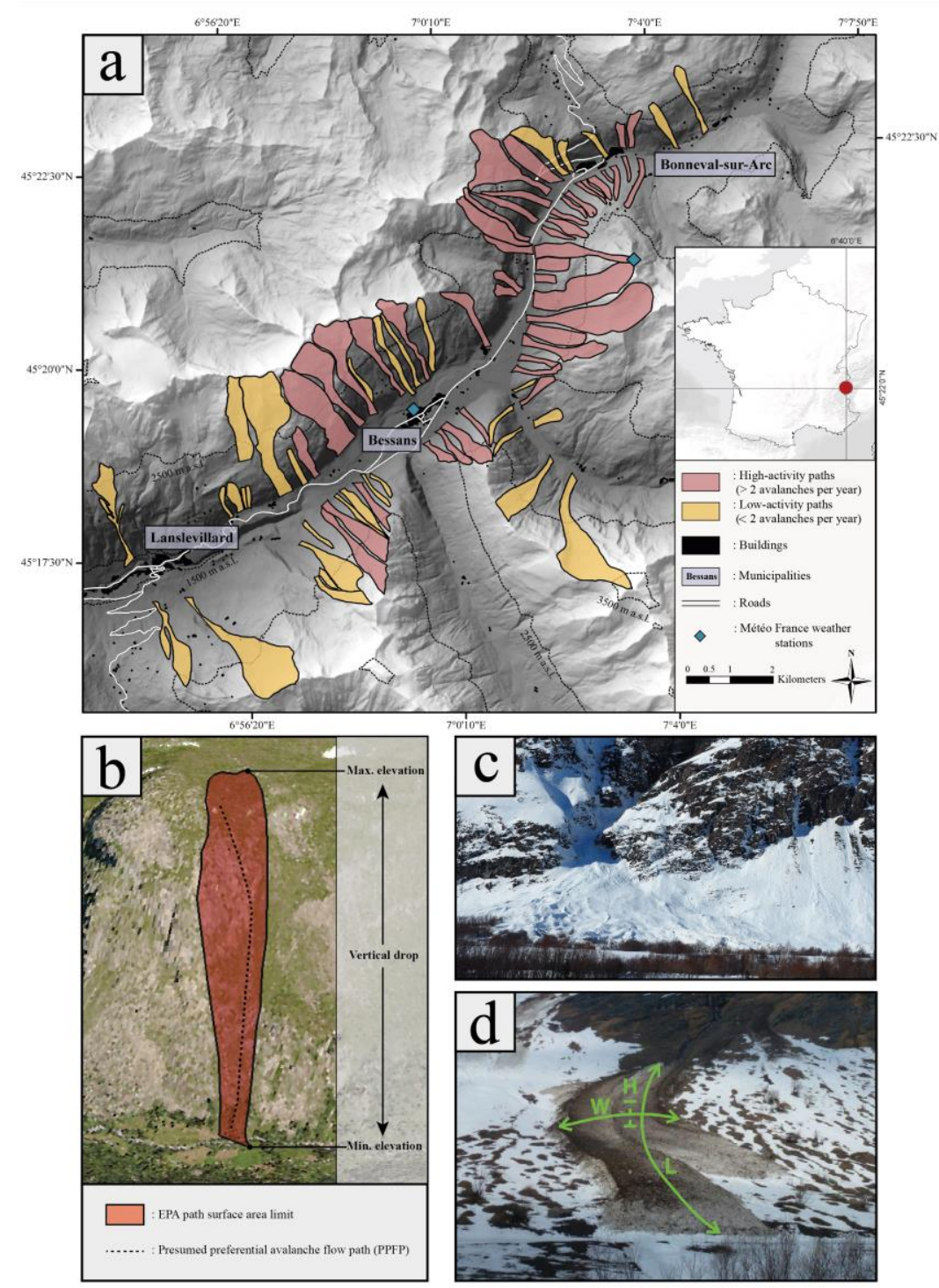


https://doi.org/10.5194/tc-2021-103

Preprint. Discussion started: 15 April 2021

(c) Author(s) 2021. CC BY 4.0 License.

(c) (i)

Figure 1: (a) Study area: snow avalanche paths from the EPA database and avalanche activity according to our completed database in the upper part of the Maurienne valley, French Alps, between 2003/04 and 2017/18; (b) Example of morphological 75 characteristics of an avalanche path from the EPA database (path $\mathbf{n}^{\circ} 44$, Bessans); (c) Snow avalanche deposit in Bessans (C) INRAE ETNA, 2018); (d) Method for visually estimating the deposit volume, H: height W: width L: length (C) INRAE ETNA, Bessans, 2019)

\subsection{Avalanche paths morphology and related volume samples}

For each studied EPA path (Fig. 1), a large set of morphological variables was calculated from a metric accuracy DEM. We

80 first defined the presumed preferential avalanche flow path (PPFP) within the path. The PPFP is the simplified thalweg of each path. For each PPFP, the length, the min, max and average slope were calculated as well as the min, max and average elevation and the vertical drop. From the whole extent of each EPA path, surface area, min, max and average slope were calculated (Supplementary Table 1). In addition, the general orientation of each path was evaluated as a categorical variable with 8 possible values corresponding to the 8 cardinal directions: N, N-E, E, S-E, S, S-W, W and N-W. For quantitative analyses, this categorical variable was further transformed into a vector of 8 binary variables. Namely, a path got assigned 1 for the binary variable corresponding to its orientation (e.g., North), and 0 for the 7 other binary variables corresponding to the 7 other directions.

The studied paths presents a mean elevation of $2281 \mathrm{~m}$ a.s.1 varying from $1936 \mathrm{~m}$ to $2942 \mathrm{~m}$ a.s.l. Concerning the dimensions the paths, the mean vertical drop is $950 \mathrm{~m}$ a.s.l and the surface area vary from 3 to $172 \mathrm{ha}$. The mean path slopes vary from $26^{\circ}$ to $49^{\circ}$ with a mean slope of $39^{\circ}$ (Supplementary table 1 ). The paths are mostly oriented either South or NorthWest. None of the paths present a North-East orientation. (Supplementary figure 1).

\subsection{Statistical analyses}

One-way analyses of variance (ANOVA) were first conducted to evaluate the significance of the partition into two subsamples (winter \& spring deposits, and "high frequency paths" with more than 2 events per year versus "low frequency paths" with less than 2 events per year). In other words, we investigated whether or not the variability of deposit volumes by path morphology varies i.) according to the season, and hence, prevailing snow and weather conditions and related types of avalanche activity, ii.) according to path's mean activity.

To shed light on the control of deposit volumes by paths morphological characteristics, Spearman correlation coefficients (r)

100 were first calculated between each descriptive variable of path morphology and the annual (Nov-Jun.), winter (Nov-Feb.) and spring (Mar-Jun.) deposit volume data series. This coefficient was chosen rather than the more classical Pearson one because the statistical distributions of deposit volumes are asymmetric, with extreme values strongly departing from the mean (Fig. 2). With a dataset of 77 individuals (one mean deposit volume per avalanche path), the relationship is significant at the 0.05 level if the Spearman coefficient is greater than 0.25 in absolute value.

105 Stepwise linear regressions were undertaken in order to determine the combination of morphological variables that best explain the variability of mean deposit volumes. This was done first using the complete database of 77 paths and 1491 
https://doi.org/10.5194/tc-2021-103

Preprint. Discussion started: 15 April 2021

(c) Author(s) 2021. CC BY 4.0 License.

(c) (i)

deposit volumes. Afterwards, distinct linear models were fitted i) on the 649 snow avalanche deposits recorded in 68 of these paths during the Nov-Feb. winter season, and ii) on the 842 snow avalanche deposits recorded in 73 of these paths during the Mar-Jun. spring season. With a stepwise procedure, the set of predictive variables retained is selected by an automatic sequence of Fisher F tests. Starting from an initial null model with no covariates and then comparing the explanatory power of incrementally larger and smaller models, it combines forward selection and backward elimination. Forward selection tests the variables one by one and includes them if they are statistically significant based on the p-value of the F statistics, while backward elimination starts with all candidate variables and tests them one by one for statistical significance, deleting any of them that are not significant on the basis of the p-value of the F statistics. We used the classical 0.05 and 0.01 probability thresholds for forward selection and backward elimination, respectively. However, before running the stepwise regression, a variable preselection was carryout out. This was made to avoid too much redundancy within potential predictors, which can lead to masks and numerical instabilities during the stepwise selection. To this aim, Pearson's correlation $\rho$ was calculated between all pairs of potential morphological variables (Supplementary Table 2). Among the strongly correlated variables ( $\rho$ $>0.8$ and $\mathrm{p}<0.001$ ), we kept as potential predictor only the one with the highest marginal correlation with deposit volumes.

120 Eventually, in order to account for potential nonlinear relationships between morphologic variables and snow avalanche deposits, more flexible neural networks models were constructed, again both for the full data set and the winter/spring subseasons. For the three data sets, the full set of 16 morphological variables previously presented was used as potential covariates (8 quantitative variables and the 8 binary variables corresponding to orientations). Both standard 3-layers and advanced 8-layers (deep learning) neural networks were developed. Models were trained using $70 \%$ of the data randomly selected from the analyzed sample of paths/mean deposit volumes with the Levenberg-Marquard algorithm (Moré, 1978). Validation was carried out with $15 \%$ of the data and model testing was carried out with the remaining $15 \%$ of the data. This typical machine learning approach allows both progressive improvement of the model with cross validations and limitation of overfitting. To account for the variability of obtained relations, a 100 bootstrap iterations was conducted, varying data partition into calibration/validation/test subsamples and initial conditions for the Levenberg-Marquard algorithm.

130 Table 1: Spearman correlation $\mathbf{r}$ between morphologic variables and avalanche deposit volumes. Values in bold are significant at the 0.05 level.

\begin{tabular}{|c|c|c|c|c|c|c|c|c|c|c|c|c|c|c|c|c|}
\hline & $\begin{array}{c}\text { Min } \\
\text { elevation }\end{array}$ & $\begin{array}{c}\text { Max } \\
\text { elevation }\end{array}$ & $\begin{array}{c}\text { Vertical } \\
\text { drop }\end{array}$ & $\begin{array}{c}\text { Mean } \\
\text { elevation }\end{array}$ & $\begin{array}{l}\text { Min } \\
\text { slope }\end{array}$ & $\begin{array}{l}\text { Max } \\
\text { slope }\end{array}$ & $\begin{array}{l}\text { Mean } \\
\text { slope }\end{array}$ & $\begin{array}{c}\text { Surface } \\
\text { area }\end{array}$ & N-W & $\mathrm{N}$ & N-E & $\mathrm{E}$ & S-E & $S$ & S-W & $\mathrm{W}$ \\
\hline Annual & 0.31 & 0.46 & 0.41 & 0.51 & -0.31 & 0.24 & -0.05 & 0.48 & -0.20 & 0.11 & & 0.15 & 0.28 & 0.16 & 0.05 & 0.02 \\
\hline Winter & 0.38 & 0.52 & 0.48 & 0.55 & -0.40 & 0.25 & -0.12 & 0.52 & -0.21 & -0.08 & & 0.28 & 0.22 & -0.17 & -0.02 & 0.19 \\
\hline Spring & 0.28 & 0.35 & 0.27 & 0.43 & -0.24 & 0.19 & 0.10 & 0.34 & -0.01 & 0.07 & & -0.05 & 0.19 & 0.16 & 0.06 & -0.09 \\
\hline
\end{tabular}


https://doi.org/10.5194/tc-2021-103

Preprint. Discussion started: 15 April 2021

(c) Author(s) 2021. CC BY 4.0 License.

(c) (i)

\section{Results}

\subsection{High spatiotemporal variability of deposit volumes and avalanche activity}

An important spatial variability in deposit volumes is observed, with the path mean deposit volume over the study period 135 varying from 1400 to $49,800 \mathrm{~m}^{3}$, the "mean of the mean" path deposit volumes being $15,100 \mathrm{~m}^{3}$ (Fig. 2). If one looks further in the distribution of mean deposit volumes, the sample mean and dispersion is significantly higher (one-way ANOVA $p=$ 0.010 ) for winter season (path mean deposit volume $=18100 \mathrm{~m}^{3}$ ) than for spring season (path mean deposit volume = $\left.12847 \mathrm{~m}^{3}\right)$.

Concerning the temporal variability, both the years 2003 and 2004 recorded particularly small deposit volumes $\left(<4000 \mathrm{~m}^{3}\right)$.

140 On the other hand, 2006 and 2014 recorded particularly large deposit volumes, with annual means of $35,800 \mathrm{~m}^{3}$ and 47900 $\mathrm{m}^{3}$, respectively. Moreover, a significant proportion of the largest deposit volumes occurred in 2017.

A strong variability in avalanche activity is observed between 2003 and 2017, with 30 low active paths ( $<2$ avalanche events per year) and 47 active paths (>2 events per year). On average, about 96 events with documented deposit volumes are triggered per year in the study area. The avalanche year 2017 was particularly active, with 526 events with documented deposits. Some of the paths are particularly active and show more than 35 events over the studied period. Paths located at Bonneval-sur-Arc and Bessans show more avalanches than those at Lanslevillard, in the lowest elevation part of the study area. Avalanche activity is stronger in spring season (860 avalanches with documented deposits) than in winter season (631 avalanches with documented deposits). Considering the frequency indicates that the high frequency paths show larger mean deposit volumes $\left(16800 \mathrm{~m}^{3}\right)$ than low frequency paths $\left(12900 \mathrm{~m}^{3}\right)$. This observation is validated by a one-way ANOVA $(p=$

150 0.029). A significant relationship exists between winter deposit volumes and the mean annual frequency of each path $(\mathrm{r}=$ $0.35 ; \mathrm{p}<0.001)$.

\subsection{Relationships between path morphology and deposit volumes}

Avalanche deposit volumes are significantly correlated with several morphological variables and with a South-East orientation. For the full (annual) data set, the best pairwise correlations are with path mean elevation $(\mathrm{r}=0.51)$, surface area $(r=0.48)$ and max elevation $(r=0.46)$. However, a clear distinction between the two seasons is observed (Table 1). For the winter season, the correlations are significant $(r>0.25)$ between deposit volumes and seven morphological variables among which mean elevation and surface area are the best predictors. The winter deposits reveal a significant correlation with an East orientation. In addition, deposit volumes are also influenced by frequency, through the positive correlation of frequency with min slope $(r=-0.24 \mathrm{p}<0.05)$ and max slope variables $(\mathrm{r}=0.27 ; \mathrm{p}<0.05)$. By contrast, correlations between path morphological variables and deposit volumes are significant in spring season for 5 variables only, and correlations are lower. Slopes variables are not significantly correlated with deposit volumes for the spring season.

Stepwise linear regressions (Fig. 2) highlight the combined effects of morphological variables on deposit volumes. For the three analyzed data sets (annual and winter/spring) none of the variables related to the PPFP is selected because of low or 
https://doi.org/10.5194/tc-2021-103

Preprint. Discussion started: 15 April 2021

(c) Author(s) 2021. CC BY 4.0 License.

(c) (1)

non-significant correlation values. By contrast, all selected variables are relative to the path surfaces: min elevation, mean elevation, min slope, max slope, mean slope, surface area and orientation. For the annual data set, the retained model includes three positive significant morphological variables increasing the deposit volumes: mean elevation and North and South-East orientation. However, $\mathrm{R}^{2}$ remains low with only $30 \%$ of the deposit volume variability explained by these variables. The seasonal stepwise linear regression shows interesting differences between the two seasons. The retained models include four significant morphological variables increasing the deposit volumes for winter season: mean elevation and east, south-east and west orientation. Only one positive variable is retained in the model for spring season: mean elevation. Resulting $R^{2}$ is higher for deposits in winter $\left(R^{2}=0.41\right)$ than for spring deposits $\left(R^{2}=0.15\right)$, which remains particularly low (Fig. 2).

Neural networks significantly enhance the predictive power with higher $\mathrm{R}^{2}$ values between the full set of morphological variables and deposit volumes, for both annual and seasonal data sets. With the 3-layer models, depending on the bootstrap iteration, best $2.5 \%$ of the models reach $\mathrm{R}^{2}$ of 0.46 (Supplementary Table 3), and, again, best fit is obtained for winter season $\left(\mathrm{R}^{2}=0.57\right.$ for the $2.5 \%$ best models, versus 0.37 for the spring season). Switching to the even more flexible deep-learning based 8-layer models even enhances these values to $\mathrm{R}^{2}=0.76$ and 0.54 for the $2.5 \%$ best models in the winter and spring season, respectively. However, on average on the 100 bootstrap iterations, retained neural network models do not reach high predictive power. For instance, the median $\mathrm{R}^{2}$ value among the 8-layer models fitted on the annual sample is 0.28 only. By contrast, as soon as a reasonably good agreement between observations and prediction is obtained (Figure 2 on which models providing $\mathrm{R}^{2}=0.61, \mathrm{R}^{2}=0.58$ and $\mathrm{R}^{2}=0.34$ are showed), discrepancies are low all over the calibration, validation and test samples, with a nearly unbiased, Gaussian-like, distribution of residuals (Supplementary figure 2). This all confirms the weak but significant control of deposit volumes by morphological variables. The increment in predictive power with regards to linear models also suggests that this control grounds at least partially on non-linear relationships. 
https://doi.org/10.5194/tc-2021-103

Preprint. Discussion started: 15 April 2021

(c) Author(s) 2021. CC BY 4.0 License.

(c) (i)
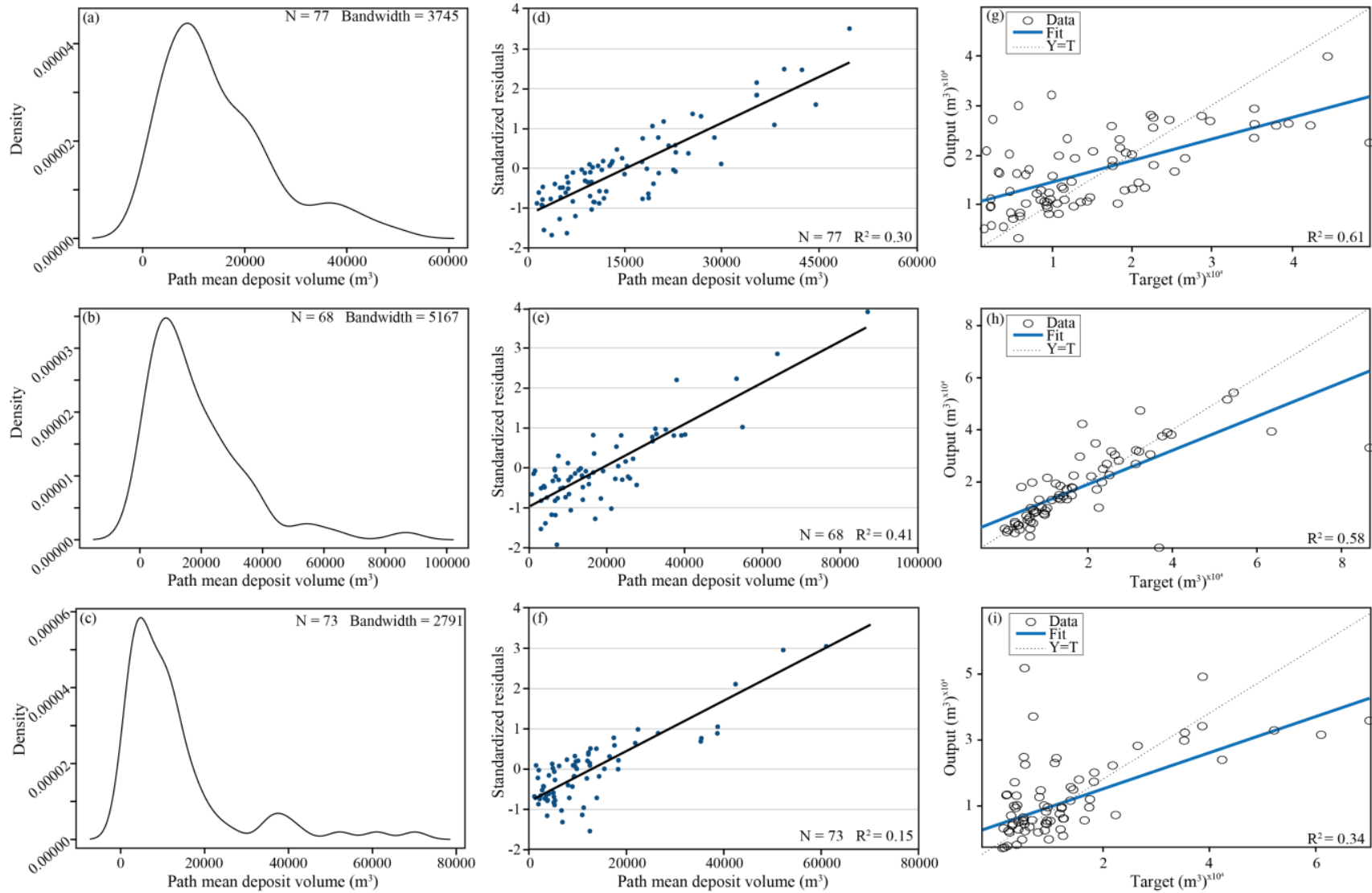

Figure 2: Statistical characteristics of snow avalanche deposit volumes. Kernel density estimation of mean path deposit volumes at the annual Nov-Jun. time scale (a), in winter, Nov-Feb. (b) and in spring, Mar-Jun. (c); Standardized residuals of stepwise linear regression results between path mean deposit volumes and path morphological variables for annual (d), winter, (e) and spring (f), linear correlation between observed deposit volume and values predicted by one neural network for the annual (g), winter (h) and spring (i) data set.

\section{Discussion, conclusion and outlooks}

In this study, using a unique dataset from 77 paths located in the upper part of the Maurienne valley, we explored the influence of snow avalanche paths morphological characteristics on deposit volumes. Using descriptive statistics, we showed a significant positive relationship between path morphological variables and the mean deposit volume at the path scale. The best simple relationships were observed with path mean elevation $(r=0.51)$ and surface area $(r=0.48)$. The seasonal subsampling analysis revealed differences in the strength of the correlation between volumes and paths morphometric 
https://doi.org/10.5194/tc-2021-103

Preprint. Discussion started: 15 April 2021

(c) Author(s) 2021. CC BY 4.0 License.

(c) (i)

variables, with higher values for winter than for spring. Only winter deposits show a weak correlation with an orientation: East $(r=0.28)$.

Linear regression did not improve the relationships much, with no more than $30 \%$ of the annual deposit volumes variability explained by a combination of morphological variables, increasing to $41 \%$ for winter deposit volumes variability but decreasing to $15 \%$ of the spring deposit volumes variability. In the three cases mean elevation is retained as a relevant predictor. Orientation variables are only retained by the annual and winter deposits model. Winter deposits show a strong positive relationship with East, Southeast and West path orientations. This indicates how important the solar radiation and/or the path positioning in respect to the prevailing wind direction may be for the properties of the snowpack, later influencing the volume deposits. However, there is no reliable data on wind direction or speed at the scale of a massif, so it is not possible to precisely characterize the wind contribution to our study. The use of a more flexible neural network approach leads to significant improvements, notably with some deep learning-based models, but, overall, the power of morphological variables to predict snow avalanche deposit volumes remains somewhat limited. Grounding on these results, we suggest that path's morphology controls deposit volumes significantly but weakly, and at least partially on the basis of non-linear relationships. This could be confirmed (or not) with further studies in different mountain areas where topography and/or avalanche activity regime is different.

Mean avalanche frequency appears as an important factor to explain these results. Indeed, slope variables partly influence the annual frequency and indirectly the deposit volumes. High frequency paths ( $>2$ events per year) present a steeper slope than low frequency paths $\left(<2\right.$ events per year) paths: $40^{\circ}$ and $37^{\circ}$, respectively. Also, high frequency paths show larger path's mean deposit volumes $\left(16,800 \mathrm{~m}^{3}\right)$ than low frequency paths $\left(12,900 \mathrm{~m}^{3}\right)$. These somewhat counterintuitive results are in line with those of Sovilla et al. (2010) that highlighted complex relationships between slope, avalanche activity and deposit volumes.

We interpret the weak relationship between mean path deposit volumes and morphological variables to be partly due the predominant control of avalanche activity by snow mechanical behavior. This especially occurs trough the mechanical thresholds involved in avalanche triggering processes (Gaume et al., 2012, Li et al., 2020), which are primarily related to snow depth and stratigraphy in the release area as well as to the slope and ground roughness in the release area. This may explain why snow avalanche deposit volumes do not seem that much affected by avalanche path size, for example. Also, mechanical release thresholds may explain the significant variations we observed in the control of winter or spring deposits by path morphology, since, from one season to another, different snow depths and stratigraphy may lead to release for different slopes / elevations as soon as the critical stress value is exceeded. Note that we did not take into account in our study the roughness of the ground, which was not possible to accurately document over the full sample of paths, but this could be an insightful perspective for further work.

More widely, we speculate that the weak relationship between volume and morphological variables may be due to an important control by climate conditions since variations in snowpack characteristics determine avalanche triggering and flow properties (Steinkogler et al., 2014, Kölher et al., 2018), and notably snow entertainment and deposition during the flow, 
https://doi.org/10.5194/tc-2021-103

Preprint. Discussion started: 15 April 2021

(c) Author(s) 2021. CC BY 4.0 License.

(c) (i)

which ultimately determines deposit volumes. Recent climate change thus impacts snow avalanches frequency, magnitude, seasonality and localization, leading, e.g., to an increasing proportion of wet snow avalanches documented in the French Alps between 1958 and 2009 (Naaim et al., 2016). Our approach should therefore now be extended to simultaneously take into account the control of deposit volumes by morphological and meteorological variables, and how these controls evolve as climate change goes on. Such an approach combining morphological and climatic variables has, for example, already been applied in Svalbard (Eckerstorfer and Christiansen., 2011) or for debris-flows in the French Alps (Jomelli et al., 2019).

\section{Data Availability}

The whole EPA avalanche data is freely availed at https://www.avalanches.fr/. The dataset of mean deposit volumes and morphological variables analyzed in this study can be requested to HK.

\section{Author contribution:}

VJ and NE designed this research. MD provided the EPA dataset. HK, VJ, NE and DG performed the analyses. HK wrote the manuscript on the basis of the input of all co-authors.

\section{Competing Interests}

The authors declare no conflict of interest.

\section{Acknowledgements}

Hippolyte KERN holds a PhD grant from Université Paris-1 Panthéon-Sorbonne. This work has received financial support from LabEx DynamiTe (ANR-11-LABX-0046) as part of the "Investissement d'Avenir" program and from INRAE, member of Labex OSUG@2020. The numerous people from ONF-RTM and INRAE that contributed to the EPA survey with the financial support of the French Ministry of the Environment are acknowledged.

\section{References}

Bartelt, P., \& McArdell, B. W.: Granulometric investigations of snow avalanches, Journal of Glaciology, 55(193), 829-833, https://doi.org/10.3189/002214309790152384, 2009

Beniston, M., Farinotti, D., Stoffel, M., Andreassen, L. M., Coppola, E., Eckert, N., Fantini, A., Giacona, F., Hauck, C., 270 Huss, M., Huwald, H., Lehning, M., López-Moreno, J.-I., Magnusson, J., Marty, C., Morán-Tejéda, E., Morin, S., Naaim, 
https://doi.org/10.5194/tc-2021-103

Preprint. Discussion started: 15 April 2021

(c) Author(s) 2021. CC BY 4.0 License.

(c) (i)

M., Provenzale, A., Rabatel, A., Six, D., Stötter, J., Strasser, U., Terzago, S., and Vincent, C.: The European mountain cryosphere: a review of its current state, trends, and future challenges, The Cryosphere, 12(2), 759-794, https://doi.org/10.5194/tc-12-759-2018, 2018

275 Eckert, N., Parent, E., Faug, T., Naaim, M.: Bayesian optimal design of an avalanche dam using a multivariate numerical avalanche model, Stochastic Environmental Research and Risk Assessment, 23, 1123-1141, 2009.

Eckerstorfer M., Christiansen H.H.: Topographical and meteorological control on snow avalanching in the Longyearbyen area, central Svalbard 2006 - 2009, Geomorphology, 134, 186-196, https://doi.org/10.1016/,j.geomorph.2011.07.001, 2011.

Favier, P., Eckert, N., Bertrand, D., Naaim, M.: Sensitivity of avalanche risk evaluation to vulnerability relations. Cold Regions Science and Technology, 108, 163-177, https://doi.org/10.1016/j.coldregions.2014.08.009, 2014.

Gaume J., Chambon G., Eckert N., Naaim M.: Relative influence of mechanical and meteorological factors on avalanche 285 release depth distributions: An application to French Alps. Geophysical Research Letters, https://doi.org/10.1029/2012GL051917, 2012.

Jomelli V.: Les effets de la fonte sur la sédimentation de dépôts d'avalanche de neige chargée dans le massif des Ecrins (Alpes françaises), Géomorphologie : relief, processus, environnement, 5, 39-57, 1999.

Jomelli V., Bertran P.: Wet snow avalanche deposits in the French Alps: structure and sedimentology, Geografiska Annaler, 83, 15-28, https://doi.org/10.1111/j.0435-3676.2001.00141.x, 2001.

Jomelli V., Pavlova I., Giacona F., Zgheib T., Eckert N.: Respective influence of geomorphologic and climate conditions on 295 debris-flows occurrence in the Northern French Alps, Landslides, 1871-1883, https://doi.org/10.1007/s10346-019-01195-7, 2019.

Kern H., Jomelli V., Eckert N., Grancher D. Deschâtres M.: Variabilité des volumes des dépôts d'avalanche et relations avec la morphologie des couloirs d'écoulement (Bessans, Savoie, France), Géomorphologie : relief, processus, environnement, 300 26, 129-140, https://doi.org/10.4000/geomorphologie.14361, 2020.

Kölher A., McElwaine J.N., Sovilla B.: GEODAR Data and the flows regimes of snow avalanches, Journal of Geophysical Research: Earth Surface, 123, 1272-1294, https://doi.org/10.1002/2017JF004375, 2018. 
https://doi.org/10.5194/tc-2021-103

Preprint. Discussion started: 15 April 2021

(c) Author(s) 2021. CC BY 4.0 License.

(c) (i)

305 Leone, F., Colas, A., Garcin, Y., Eckert, N., Jomelli, V., \& Gherardi, M.:. Le risque avalanche sur le réseau routier alpin français. Évaluation des impacts et cartographie de la perte d'accessibilité territoriale. Journal of Alpine Research| Revue de géographie alpine, (102-4), https://doi.org/10.4000/rga.2491, 2014

Li X., Sovilla B., Jiang C., Gaume J.: The mechanical origin of snow avalanche dynamics and flow regime transitions, The 310 Cryosphere, 14, 3381-3398, 2020, https://doi.org/10.5194/tc-14-3381-2020

Mc Clung D.M., Gauer P.: Maximum frontal speeds, alpha angles and deposit volumes of flowing snow avalanches, Cold Regions Science and Technology, 153, 78-85, https://doi.org/10.1016/j.coldregions.2018.04.009, 2018.

315 Moré, J. J.: The Levenberg-Marquardt algorithm: implementation and theory, Numerical analysis, 105-116, 1978

Naaim M., Eckert N., Giraud G., Faug T., Chambon G., Naaim-Bouvet F., Richard D.: Impact du réchauffement climatique sur l'activité avalancheuse et multiplication des avalanches humides dans les Alpes françaises, La Houille Blanche, 6, 12-20, https://doi.org/10.1051//hb/2016055, 2016.

320

Sovilla B., McElwaine J.N., Schaer M., Vallet J.: Variation of deposition depth with slope angle in snow avalanches : Measurement from Vallée de la Sionne, Journal of Geophysical Research, 115, 13 p. https://doi.org/10.1029/2009JF001390, 2010.

325 Sovilla B., McElwaine J.N., Louge M.Y.: The structure of powder snow avalanches, Comptes Rendus Physique, 16, 97-104, https://doi.org/10.1016/j.crhy.2014.11.005, 2015.

Steinkogler W., Sovilla B., Lehning M.: Influence of snow cover properties on avalanches dynamics, Cold Regions Science and Technology, 97, 121-131, https://doi.org/10.1016/j.coldregions.2013.10.002, 2014.

Zgheib T., Giacona F., Granet-Abisset A.N, Morin S., Eckert N.: One and a half century of avalanche risk to settlements in the upper Maurienne valley inferred from land cover and socio-environmental changes. Global Environmental Change, 65, https://doi.org/10.1016/j.gloenvcha.2020.102149, 2020. 